\title{
腎移植後の大腿骨頭壊死について
}

\author{
済生会八幡病院 整形外科 \\ 内 藤 正 俊 - 黑木健 文 \\ 済生会八幡病院 腎臟部 \\ 合 屋忠信・佐々木 春 彦 \\ 阿 部 哲 哉・藤 永隆 \\ 九大病院 整形外科 \\ 杉岡洋一一香月一朗 \\ 福岡日赤病院 整形外科
}

内 藤 英 俊・河野渉

福岡日赤病院 腎臟部

藤見惺・原田篤実

\section{Avascular Necrosis of Femoral Head after Renal Transplantation}

by

\author{
Masatoshi Naito, Tadanobu Goya, Haruhiko Sasaki, \\ Tetsuya Abe, Takashi Fujinaga \\ and Takefumi Kuroki \\ Saiseikai Yahata Hospital \\ Yoichi Sugioka and Ichiro Katsuki \\ Department of Orthopaedic Surgery, Faculty of \\ Medicine, Kyushu University \\ Hidetoshi Naito, Wataru Kawano, Sei Fujimi \\ and Atsushi Harada \\ Fukuoka Redcross Hospital
}

\begin{abstract}
Twenty patients whose grafts were still functioning twelve months after renal transplantation constitute this study. The patients-14 males 6 females-were aged from 14 to 41 years at the time of transplantation. They were followed-up for between 10 and 143 months after transplantation. Six ( 8 hips) of the twenty patients developed avascular bone necrosis in the femoral head. The interval between transplantation and the onset of pain over the affected hip varied between 5 and 24 months, with an average of 12.8 months. The total amounts of steroids given from the time of transplantation until the onset of the symptoms varied between 8.1 and $15.8 \mathrm{~g}$., with an average of $11.5 \mathrm{~g}$.. At the initial roentgenographical examination the patients with this complication were all classed as in Grade 1 or Grade 2 of the disease of the basis of the roentgenographic findings ${ }^{2)}$. During the first twelve months following transplantation there were no significant differences between the groups with and without this complication as regards the total intake of azathoprine or the total does of steroids.
\end{abstract}


表 1 症例

\begin{tabular}{|c|c|c|}
\hline & $\begin{array}{c}\text { 大腿骨頭壞死群 } \\
6 \text { 例 } 8 \text { 関節 }\end{array}$ & $\begin{array}{c}\text { 非大腿骨頭壞死群 } \\
14 \text { 例 }\end{array}$ \\
\hline $\begin{array}{l}\text { 性 } \\
\text { 年 } \\
\text { 堅移植からの経過観察期間 } \\
\text { 婜移から発症までの期間 } \\
\text { 発症からの経過観察期間 }\end{array}$ & $\begin{array}{c}\text { 男性 } 5 \text { 例, 女性 } 1 \text { 例 } \\
22 \text { 才 } 40 \text { 才, 平均 } 30.3 \text { 才 } \\
\text { 19〜 } 43 \text { 力月, 平均 } 27.8 \text { 力 } \\
5 \sim 24 \sim \text { 力, 平均 } 12.8 \text { 力月 } \\
5 \sim 20 \text { 力月, 平均 } 14.2 \text { 力月 }\end{array}$ & $\begin{array}{c}\text { 男性 } 9 \text { 例, 女性 } 5 \text { 例 } \\
14 \text { 万加 } 41 \text { 才, 平均 } 28.4 \text { 才 } \\
\text { 10〜144力, 平均 } 67.9 \text { 力月 }\end{array}$ \\
\hline
\end{tabular}

はじめに

近年，腎不全に対する治療法として腎移植が積極的 に行われるようになってきている，乙れに伴い腎移植 後の長期生存例が年々増加してきている．腎移植後の 免疫抑制療法として副腎皮質ステロイド剂が大量に使 用されており，乙れによると考えられている大腿骨頭 壊死がこれらの症例に高頻度に合併することはよく知 られている.

我々は腎移植後に発症した大腿骨頭壞死 6 例（以下 $\mathrm{AN}$ 群と略す）を経験したので， $\mathrm{AN}$ 群と現在まで大 腿骨頭壊死を発症していない 14 例（以下非 AN 群之 略す）とについて若干の因子に関し検討を加えたので 報告する.

\section{対 象}

済生会八幡病院および福岡日赤病院腎グループによ り腎移植をうけた症例中移植腎が 1 年以上機能した 20 例を対象とした（表 1 ）。20例中 6 例に大腿骨頭壊死 が発症し，その発症頻度は $30 \%$ であった. AN 群 6 例の性別は女性 1 例, 男性 5 例であり, 非 AN 群で は女性 5 例, 男性 9 例であった。腎移植時の平均年令 は $\mathrm{AN}$ 群では 30.3 才, 非 $\mathrm{AN}$ 群では 28.4 才であっ た. $\mathrm{AN}$ 群の羅患側は 1 例 4 例，両側 2 例であった。 股関節部から大腿部における疼痛を訴えた時期を発症 とし，腎移植から発症までの期間は平均 12.8 力月で あり，発症からの経過観察期間は平均 14.2 力月であ った。腎移植前の血液透析期間はついて

移植前の血液透析期間は $\mathrm{AN}$ 群が平均 41.3 力月, 非 $\mathrm{AN}$ 群が平均 22.6 力月であり， $\mathrm{AN}$ 群が非 $\mathrm{AN}$ 群 之比較し平均 19 力月間長期であったが両者間に有験 差は認められなかった。

腎移植前後の血清クレアチニン值について

移植 1 週前の血清クレアチニン值は $\mathrm{AN}$ 群が平均 $3 \mathrm{mg} / \mathrm{dl}$ 大であったが, 移植後 1 年間の血清クレアチ
腎移植後の脂質代謝について

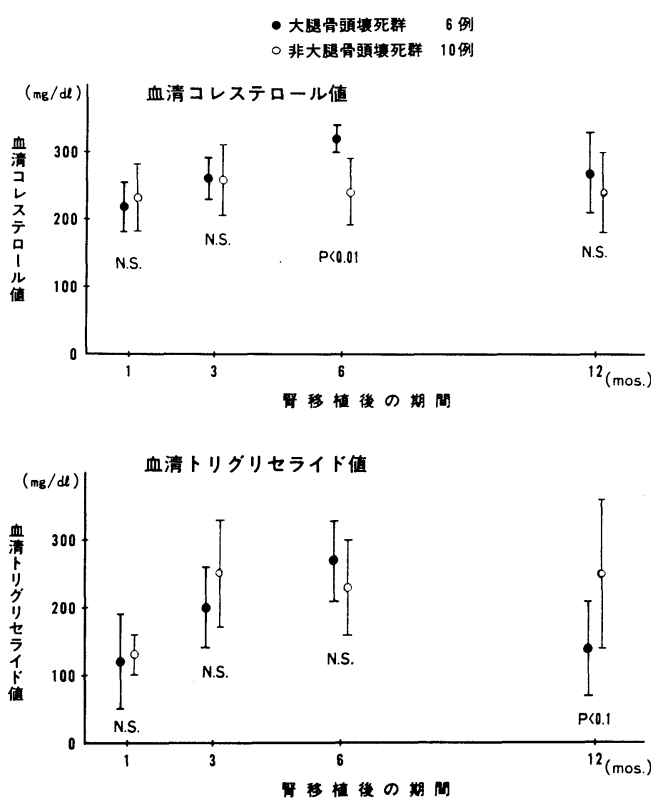

図 1

ニン值については $\mathrm{AN}$ 群と非 $\mathrm{AN}$ 群の間に有意差は 認められなかった。

腎移植後 1 年間の鉱質代謝について

血清カルシウム值执よび血清リン值について比較検 討したが, $\mathrm{AN}$ 群と非 $\mathrm{AN}$ 群の間に有意差は認めら れなかった。

腎移植後 1 年間の脂質代謝について（図 1 )

1. 血清コレステロールについて

移植後 1 力月, 3 力月, 12 力月目では $\mathrm{AN}$ 群と非 $\mathrm{AN}$ 群との間に血清コレステロール值の有意差は認め られなかった．移植後 6 力月目の比較では $\mathrm{AN}$ 群が 非 AN 群と比べ平均 $84 \mathrm{mg} / \mathrm{dl}$ 有意に大であった.

2. 血清トリグリセライド值について

腎移植後 12 力月目に於いて，血清トリグリセライ 
ド値は AN 群の方が非 AN 群と比較し $115 \mathrm{mg} / \mathrm{dl}$ 小で論ったが有意の差は認められなかった。

\section{免疫抑制剤について}

1. azathioprine について

Azathioprine については経口投与であり，移植後 1 年間の総投与量および体重 $1 \mathrm{~kg}$ 当たりの投与量に ついて $\mathrm{AN}$ 群と非 $\mathrm{AN}$ 群の間に有意差は認められ なかった。

2. ステロイド剂について

ステロイド剂は predonisolone と methyl predonisolone が用いられている. Predonisolone は 経口投与であり，移植後 1 力月までは 1 日平均 30 $\mathrm{mg}$, 以後減量し 6 力月後で 1 日 $15 \mathrm{mg}, 12$ 力月後で 1 日 $10 \mathrm{mg}$ が基準投与量として用いられている. Methyl predonisolone は静注されておゔ，拒絶反 応の場合パルス療法として毎日 500 から 1,000 mg を 3 日間使用されている. Methyl predonisolone は predonisolone に換算し移植後 1 年間のステロイド 投与量に関し $\mathrm{AN}$ 群と非 $\mathrm{AN}$ 群とについて比較した が，ステロイド総投与量抒よび体重 $1 \mathrm{~kg}$ 当たりの投 与量とむに両者間に有意差は認められなかった. 腎移 植から発症までの期間およびステロイド総投与量との 間に明確な関連は認められなかったが，6例ともステ ロイド総投与量 $8,000 \mathrm{mg}$ 以上で発症していた（図

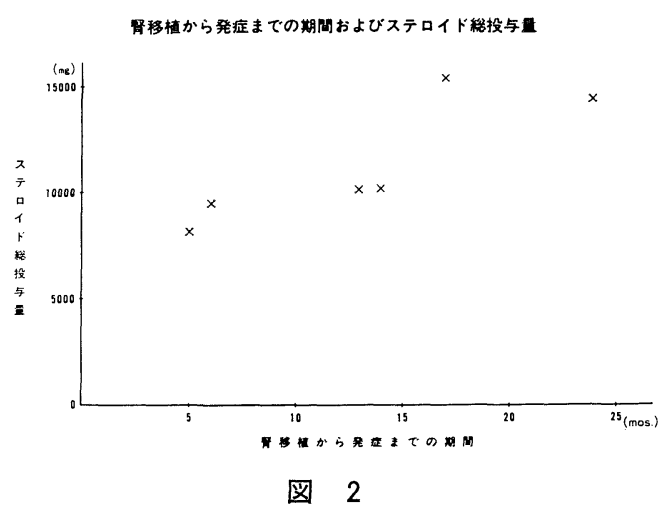

表 2 初診時のX線所見 6 例 8 関節

I 度：骨頭は球形を保つ 頸部骨萎縮像

II 度：骨頭の軽度扁平化

III 度：骨頭の強い陷落

IV 度：III度十関節裂隙狭少化
2).

\section{$\mathbf{X}$ 線所見について}

$\mathrm{AN}$ 群 6 例 8 関節の初診時 $\mathrm{X}$ 線所見を 杉岡の分類 ${ }^{2}$ でまとめると骨頭の軽度扁平化を呈するII度が最も多 く， 8 関節中 5 関節が度であった（表 2 ）。 また I 度では頸部骨梁萎縮像が 3 関節であった。

\section{参 考 文 献}

1) Elmsted, E.: Skeletal complications in the renal transplant recipient. A clinical study. Acta Orthop. Scand. Supplementum 52: 7-38, 1983.

2) Sugioka, K.: Transtrochanteric rotational osteotomy of the femoral head for the treatment of osteonecrosis. Follow-up statitistics. Clin. Orthop. 169: 115-126, 1982.

\section{発 言 大分医科大学 真角 昭吾}

(1) 先生の今回の調査結果は私が北里大学在任中に 行ってきた報告とほぼ同様と思います。

(2) 今回骨壊死発生頻度は $30 \%$ とのことですが, 移植症例がふえれば発生頻度そのものは低下してくる あのと思います. 北里例では15〜16\%に落ちている ようです.

(3) 骨壊死発生の予防策は steroid 剂を兔疫抑制 に用いている限り，ないのではないでしょうか．別の 免疫抑制剂の開発とか 移植免疫の発展が 期 待されま す. 病因の 1 つに microfracture 説があるので, 今 の所は腎移植の術前, 術後にビタミン $\mathrm{D}_{3}$ を投与する とか, 骨壊死を早期に発見してクラッチの使用, 日常 生活の指導を行なう位にとどまっています.

\section{質 問長崎大学 池田 定倫}

腎移植後の avaswlar necrosis の発生を防止する ような方法あるいはその進行を止めるような方法を何 か取られていたら教えて下さい。

\section{解 答済生会八幡病院 内藤正俊}

予防策は不明であり，とっていない，進行の防止に ついては，患側に荷重をしないように勧めておりま 市. 